\title{
Remitting behaviors and intention to return home of Thai migrant workers in Australia: A study of income, employment and legal satisfaction
}

\section{Potjaporn Joonlaoun *}

\author{
Thammasat International Trade Law and Economics, Thammasat University, Bangkok, Thailand
}

\author{
Key Words \\ Migrant workers \\ Remittances \\ Determinants \\ Intention to return
}

Received: 12 April 2016

Accepted: 13 May 2016

Published: 27 February 2017

\begin{abstract}
This study analyzed a correlation between intention to return home and remitting behaviors of Thai migrant workers in Australia and determinants of their decisions to return. Like other developing countries, Thailand's economy considerably relies on international capital inflows, including workers' remittance. Based on New Economics of Labor Migration and Three Waves Theory, the author hypothesized that remitting behaviors of Thai migrant workers in Australia correlate with their intention to return home. Further to test this hypothesis, this paper also identifies the determinants of return intention. The author surveyed a hundred Thai migrant workers in Australia, particularly in the service sector, and use Pearson Correlation and Stepwise Regression to analyze data. The results are reported in descriptive analysis. Correlation coefficients are used to quantify the association between continuous variables. The analysis shows that intention to return home induces remittances in terms of amount per year and proportion to income. Having further considered the determinants to return home of workers, income and employment satisfaction seem not to affect their decisions as hypothesized significantly. On the other hand, they are preferably satisfied in legal issues, particularly visa regulations and labor protections, and they became important negative factors of intention to return. Furthermore, international agreement and some legal instruments such as the agreement between Thailand and Australia for the avoidance of double taxation and the prevention of fiscal evasion concerning taxes on income, Fair Work Act 2009 and Labor Protection Act B.E. 2541, are also used to deepen the understanding of the economic outcome.
\end{abstract}

(C2017 The Author(s). Published by TAF Publishing.

\section{INTRODUCTION}

Like migrant workers in other developing countries, high income and hope for better life always attract some Thai workers to travel aboard to seek a better job opportunity. Most of them are working in developed countries which offer comparative advantages in terms of income and employment opportunity such as Taiwan, Korea, Sweden and Japan. In 2014, Thailand Overseas Employment Administration (TOEA) (2015) reported that 69,664 Thai workers or $0.17 \%$ of Thai workforce were sent to work abroad. In the same year, Thailand received remittance of 5.9 billion USD, accounts for over $1.46 \%$ of the country's GDP (The World Bank, 2014). These Thai migrant workers have contributed consistent economic value through remittances and human capital.

Having realized this value, the government has been creating a number of programs to promote Thai workers to work abroad such as occupational training programs to upgrade labors' capability, bilateral and multilateral agreement on human movement to extend overseas employment channels and some legal assistance to those interested. In ad-

\footnotetext{
${ }^{*}$ Corresponding author: Potjaporn Joonlaoun

†Email: k_happy18@hotmail.com, potjaporn.joonlaoun@dfat.gov.au
} 
dition to the attempt to increase the number of workers, policy makers need to know factors that encourage them to send their income back home and to identify characteristics of migrant workers who potentially return to Thailand permanently.

Based on previous studies, Intention to return to home country plays an important role to stimulate remittances of migrant workers. Therefore, it is worth to know that in case of Thai migrant workers in Australia, if this conclusion can be applied or not and what factors determine their decisions to return to Thailand or remain in Australia permanently. Satisfaction in income and employment in a host-country is assumed to be one of significant determinants. However, it is important to note that, with other economic and social limitations, whether income and employment satisfaction alone can still influence intention to return of Thai migrant workers in Australia. This study also reveals another fact that is little found on previous studies, whether legal aspect can be counted as one of the return determinants.

A hundred of Thai migrants who currently work lawfully in Australia particularly in service sector were surveyed. Respondents were asked to provide their general information such as age, marital status, employment, income including their intention to return home permanently. In addition, respondents were also requested to rate their satisfactions towards their incomes, employments and legal circumstances in Australia. General information of respondents was analyzed by basic statistical analysis method namely Mean and Standard Deviation.

With SPSS predictive analytics software, the author uses Pearson Correlation analysis to prove a correlation between workers' intention to return home and remitting behaviors, and uses Stepwise Regression analysis to forecast the effect of their income, employment and legal satisfaction for intention to return home.

To deepen understanding of the survey outcome, some legal instruments namely Fair Work Act 2009, Thai Labor Protection Act B.E.2541, Australian visa regulations, taxation and Agreement between Thailand and Australia for the Avoidance of Double Taxation and the Prevention of Fiscal Evasion with Respect to Taxes on Income were also brought to explain on the last chapter of the paper.

\section{THEORETICAL ISSUES AND PREVIOUS STUDIES REVISION}

\section{NELM and Three Waves Theory}

There is consistency in a relationship between intention to return to home country and remitting behaviors of migrant workers proposed by different scholars and models. The New Economics of Labor Migration (NELM) developed by Stark and David (1985) explains this relationship in form of a life cycle perspective. In this perspective, it begins the cycle with negative remittance resulting from their first investment for coming to Australia and arrival expenses. Remittance increases after workers start having their own salary and they would continue sending their money back home as remittance is considered as a tie to the country. However, remittance decreases when workers decide to settle down in a host country and it may cease completely in the end. At this point, workers would be considered as an income insurer instead of income supporter. This means workers are obligated to consistently send their money back home to assure good finance of the family as an income supporter instead of sending when needed as an income insurer.

Poirine (1997) created another theory called Three Waves Theory to explain this relationship. Three Waves means three phases of remittances; pay back phase, loan phase and investment phase. A significant portion of income remitted to a family in the first phase is for paying back the loan which derived from an investment. In the second phase, migrants tend to send their money to support and provide a loan to family members. However, not 
all migrants are expected to follow this approach. As a result, a portion of remittances in this phase drops down. When migrants have decided to return to their home countries, they will remit most of their accumulated capital to invest at home. Therefore, the amount of remittances in this phase increases but declines when migrants decide to settle down in host countries.

Obviously, many of the available empirical evidences support both theories such as a study of remittance behavior of Greek (Glytsos, 1997; Ahlburg and Richard, 1998), Samoa and Thonga migrants in Australia (Brown et al., 2012) Philippines in Taiwan (Atienza and Alan, 2013), Romanians in different countries (Goschin et al., 2010) and Moroccan in France (Bouoiyour and Amal, 2014). Additionally, they are supported by statistical data of Australian Center for Financial Studies (Davis and Martin, 2012).

\section{The Two Contradict Theories Over Determinants of Intention to Return}

An economic factor is a primary motivator causing international migration. It is also considered as a main factor encouraging migrants to return home. Having studied economic determinants of return intentions, there are two main sides of theories explaining this. Neoclassical Economic Theory (Constant and Douglas, 2002) says that migrants who do not achieve income and employment in host countries as expected before migrating are likely to return home. On the contrary, New Economics of Labor Migration (NELM) (Stark, 1991) believes that migrants will decide to return only when they have succeeded in earning the expected income and employment while ones who have not done so tend to postpone their returns until they achieve their economic expectations.

Both theories are supported by different empirical studies, for example, the findings of the study of Zimbabwean workers in South Africa by Makina (2012) are in line with Neoclassical Economic Theory while the study of Tonga and Samoa workers in Australia by Ahlburg and Richard (1998) is consistent with NELM as well as the study of Moroccan workers in France by Bouoiyour and Amal (2014).

Interestingly, very few studies mention legal issues as factors of return intention. Most are only focusing on economic and social dimensions. It, however, will be revealed in this study.

\section{Overview of Migrant in Australia}

After World War II, majority of migrant workers in Australia entered the country under Settler Migration Program. Ideally, these workers should be treated fairly and equally without discrimination, however, in fact, they were recognized as migrant-based underclass or secondary labor market among Australian-born people. Unlike migrant workers from Settler Migration Program, professional skill labors who entered the country from selection criteria seemed to gain more benefits from this program. Especially, when the government brought visa as a method of selection, professional skill labors gained most benefits among others (Withers, 1986; Suhaili et al., 2015; Frantz and Ashutosh, 2016).

According to the Labor Force Status and Characteristics of Migrant Surveys by Australian Bureau of Statistics in 2004, labor force participation between migrants and Australians born was not significantly different in terms of participation rate and types of occupation. Important characteristics that were found affecting migrants' employment participation were language skill and migration pathway. It figures that migrants with better language skill gained better employment participation. Also, it is reasonable that migrants who had been employed in their home countries before traveling to Australia had more employment engagement than those who had no employment background in their own 


\section{Thai Migrant in Australia}

Although Thai people are not considered as one of majority groups of migrants in Australia, its increase in number has remarkably surpassed others in the last 30 years resulting in the wide spread of Thai culture. According to the Australian Census 2011, there were 45,456 Thai nationals residing in Australia and 38\% of this was living in New South Wales especially in a big city like Sydney followed by Victoria, Queensland and Western Australia respectively. Average age was between 25-39 years old and 2 of 3 were women. It can be implied from this figure that most of these women first entered Australia by marrying Australians (Beasley et al., 2014).

\section{Education, Employment and Income}

Figure 1-3 show the current situation of education, employment and income of Thai-born residents compared to the total population. According to Figure 1, Thais gain higher education than overall country's population by acquiring bachelor's degree twice more and the participation of employment is only little less. That is to say the employment rate of Thai labors is $66.4 \%$ while that of the overall country is $65 \%$. However, the higher education level does not contribute to better job and income. Figure 2 also disclosed that nearly $25 \%$ of Thai workers are working as labors while only little over $10 \%$ working in a professional category. Comparing to Thais, country's overall population engaged in labor works is only $10 \%$ and nearly $25 \%$ in professional level as shown on Figure 2. Apart from that, the number of Thai-born living in Australia without income is nearly 3 times higher than the overall population, over $16 \%$ as shown in Figure 3 (Beasley et al., 2014).

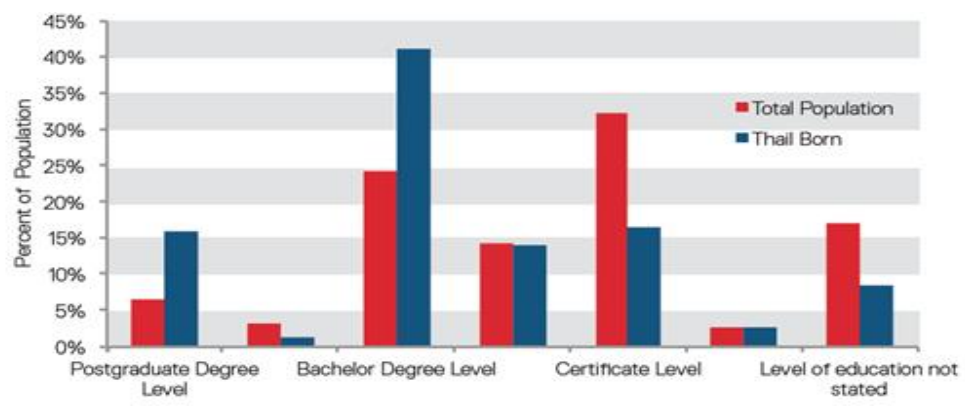

FIGURE 1. Education of Thai-born residents compared to the total population in 2014 Source: Thailand in Australia. Sydney: The University of Sydney.

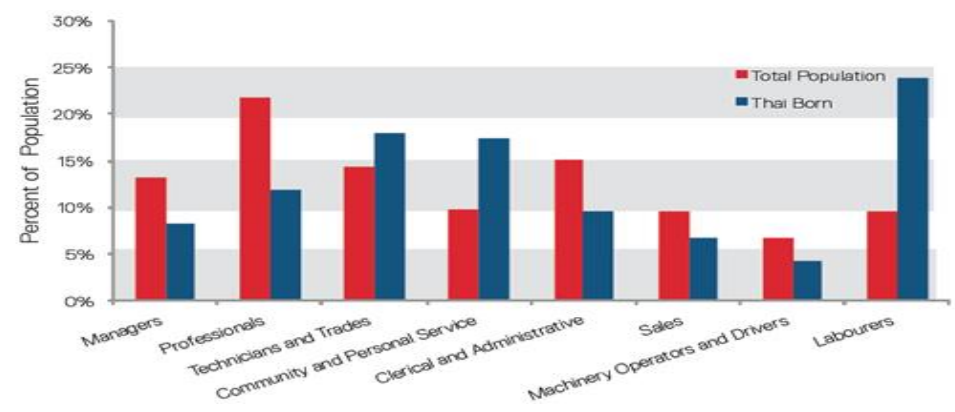

FIGURE 2 . Occupation of Thai-born residents compared to the total population Source: Thailand in Australia. Sydney: The University of Sydney 


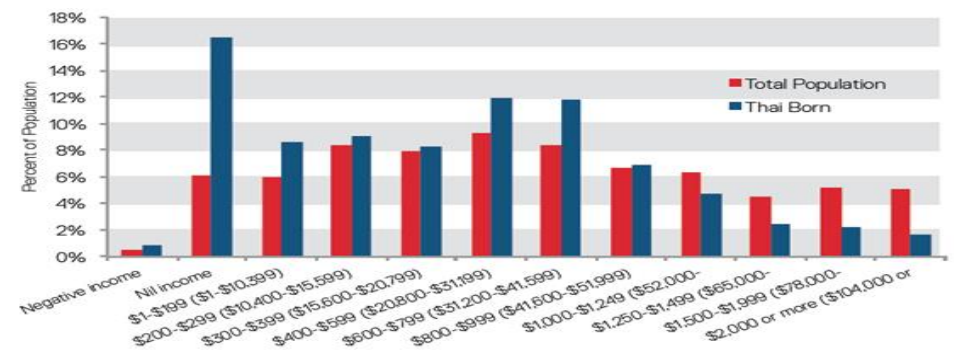

FIGURE 3 . Income of Thai-born residents compared to the total population Source: Thailand in Australia. Sydney: The University of Sydney

\section{Thai Investment in Australia}

"Investment from Thailand has had by far the fastest growth amongst Australia's top 20 investor countries. The stock of Thai investment in Australia grew more than 20 times between 2007 and 2012, from 338 million to 7.3 billion" (Beasley et al., 2014).

Some power Thai companies have begun their tremendous investment in Australia such as Electricity Generating Authority of Thailand-EGAT, Banpu, PTT Exploration and Production Public Company (PTT EP), Mitr Phol Sugar and Minor International (Beasley et al., 2014). Investment of Thai companies does not lead to only capital and technology transfer but also human resources. These investments have extended the opportunity for Thai to work temporarily in their companies as intra-corporate transferees and specialists as indicated on Thailand Australia Free Trade Agreement. However, they still need to meet criteria set out in visa regulations in Australian domestic law.

\section{CONCEPTUAL FRAMEWORK}

The relationships between intention to return, remitting behaviors and its determinants can be conceptualized at a two-stage relationship, depicted in Figure 4 where a set of three determinants, employment, income and legal satisfactions impact intention to return, which in turn determines remitting behaviors in terms of amount, frequency and proportion to income.

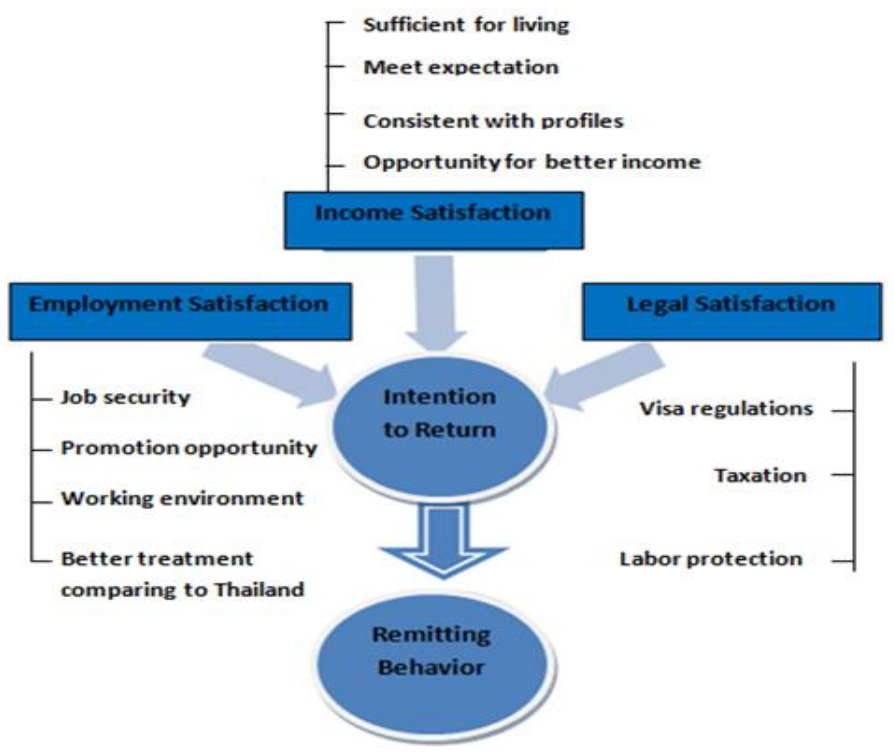

FIGURE 4 . Conceptual framework 
The issues that are brought to measure employment satisfaction are job security, promotion opportunity, working environment and better treatment comparing to Thailand while income satisfaction is measured by the questions that whether the income is sufficient for living, meeting expectation, consistent with their profiles and opportunity for a better income.

For legal satisfaction, there are three issues brought to judge legal satisfaction which are visa regulations, taxation and labor protection. In the next section, the analysis methods of each relationship are discussed in more details.

\section{Framework Components}

Intention to Return: Respondents were asked to indicate whether they intend to return to Thailand permanently. Only closed-ended questions were provided, so respondents had to answer 'Yes' or 'No'.

Remitting Behaviors: In general information part, respondents would declare their incomes, remittances per year and frequency of remitting. Remittance per income was then calculated from the available information and has been taken into account as one of the remitting behaviors.

Income, Employment and Legal Satisfaction: Respondents were requested to rate their satisfactions on each question by rating $1-5,1$ refers to strongly disagree and 5 is strong agree. Box 1-3 show the questions that were used in the questionnaires.

Box 1: Questions relating to income satisfaction

- Is your income sufficient for living and meeting with your living expenses?

- Does your current income meet your expectation that you set before moving to Australia?

- Is your income consistent with your education and capacity?

- How is your opportunity to gain more income?

Box 2: Questions relating to employment satisfaction

- Is your current employment secured? - Does your employment offer you promotion or progress opportunity?

- How is your opportunity to gain more income?

- Comparing to Thailand, you as a worker are treated better than in Australia.

Box 3: Questions relating to legal satisfaction

Visa regulations

- Do regulations support you to become an Australian permanent resident and citizen?

- Do visa regulations obstruct you to bring your family to live in Australia with you?

Taxation

- Are taxes you have paid worth what you have received?

- Does paying taxes in Australia benefit you more than paying in Thailand?

Labor protection

- Comparing to Thailand, are you better protected by labor law in Australia?

- If you have any arguments relating to work, you are confident that you will be fairy treated by labor law?

- Are you being treated as equally as Australians?

\section{STATISTICAL PROCESS}

Pearson Correlation and Stepwise Regression are the two statistical processes that were used to analyze data through SPSS software package. Since only the degree of relationship between intention to return and remitting behavior is quantified, Pearson Correlation analysis was the most appropriate method to use.

On the other hand, it is important to estimate the conditional expectation of intention 
to return given the three variables, income, employment and legal satisfaction. As such, stepwise regression became the best method for this analysis.

\section{Functional Equations}

Pearson Correlation was used to analyze a relationship of intention to return and remitting behaviors in the following functional equation when other variables are held fixed:

$Y_{R}=\beta o+\beta_{1} I+\beta_{2} A+\beta_{3} S+\beta_{4} M+\beta_{5} S+\beta_{6} O+\beta_{7} W+\epsilon$

Stepwise Regression was used to analyze a relation of income, employment and legal satisfaction and intention to return in the following functional equation when other variables are held fixed:

$Y_{1}=\beta_{0}+\beta_{1} F+\beta_{2} E+\beta_{2} C+\beta_{4} L+\beta_{5} V+\beta_{6} T+\epsilon$

\section{Functional Symbols:}

$Y_{R}=$ the amount of remittance per year

$Y_{1}=$ intention to return

$\mathrm{A}=$ age

$\mathrm{S}=\operatorname{sex}$

$\mathrm{M}=$ marital status

$\mathrm{F}=$ family members in Australia

$\mathrm{O}=$ occupation

$\mathrm{E}=$ income satisfaction

$\mathrm{C}=$ employment satisfaction

$\mathrm{L}=$ legal satisfaction

$\mathrm{V}=$ visa status

$\mathrm{T}=$ Time spent in Australia

$\mathrm{W}=$ income per year

\section{Data}

Data were collected from a hundred of Thai workers who are legally employed in five service sectors classified by Australian and New Zealand Standard Industrial Classification (ANZSIC), transport, retail services, accommodation and food services, social assistance and recreation services. These sectors are assumed to be the most popular works among Thai people in Australia. To assure legal employment, respondents are requested to indicate their visa status, permanent resident, temporary work or student visa, which allows them to work legally under certain conditions.

The data show $68 \%$ of respondents have intention to return and $75 \%$ of this is female population. The average ages of both groups are only slightly different, 30 for male and 32 for female. Comparing to the return group, the not-return has higher average ages, 36 for male and 35 for female. The data also show the return group gains more income than the other, average 2,618 AUD per month while only 2,484 AUD for the not-return.

Regarding remitting behaviors, it obviously shows that respondents who have intention to return send more money back home in all measurements, amount per year, frequency and proportion to income. The return group remits money average 5,662 AUD with 8 times per year and this is calculated as $17.79 \%$ of their income. On the other side, the not-return group remits money only 3,034 AUD with 5 times per year which can be calculated as $9 \%$ of their income. 
RESULTS

The result was set significant at a significance level of 0.05 and the author weighed the strength of index into 3 levels as followed:

TABLE 1. Weighed the strength

\begin{tabular}{ll}
\hline \hline Significance & Interpretation \\
\hline $0.01-0.30$ & Related in a low level \\
$0.31-0.60$ & Related in a medium level \\
$0.61-1.00$ & Related in a high level \\
\hline \hline
\end{tabular}

Pearson Correlation Analysis of Intention to Return And Remitting Behaviors

According to the descriptive analysis, intention to return related to remitting behaviors in terms of amount per year and proportion to income with Pearson Correlation coefficient (r) of 0.207 and 0.219 respectively. Conversely, it does not relate to remitting frequency with a significant level larger than 0.05 .

TABLE 2. Sex and age of respondents categorized by intention to return

\begin{tabular}{lllll}
\hline \hline & Return & \multicolumn{3}{c}{ Not Return } \\
\hline Sex & Male & Female & Male & Female \\
\hline Number & 17 & 51 & 3 & 29 \\
Average age & 30 & 32 & 36 & 35 \\
\hline \hline
\end{tabular}

TABLE 3. Marital status, family members in Australia and visa status of respondents categorized by intention to return

\begin{tabular}{lllllll}
\hline \hline & \multicolumn{2}{c}{ Marital Status } & & Family Members in Australia & \multicolumn{3}{c}{ Visa Status } \\
\hline & Single & Other & Yes & No & Temporary & Permanent \\
\hline Return & 39 & 29 & 34 & 34 & 50 & 18 \\
Not Return & 9 & 23 & 26 & 6 & 9 & 23 \\
\hline \hline
\end{tabular}

TABLE 4. Average income and occupation of respondents categorized by intention to return

\begin{tabular}{lccc}
\hline \hline & Average Income per Month (AUD) & Occupation & \\
\hline & & Employee & Business Owner \\
\hline Return & 2,618 & 64 & 4 \\
Not Return & 2,484 & 27 & 5 \\
\hline \hline
\end{tabular}

TABLE 5. Remittance frequency, amount of remittance per year, proportion of remittance per income categorized by intention to return

\begin{tabular}{llllllllll}
\hline \hline & & Frequency per Year & \multicolumn{2}{c}{ Amount per Year (AUD) } & Proportion per Income & & & & \\
\hline & Ave & Max & S.D. & Ave & Max & S.D & Ave & Max & S.D. \\
\hline Return & 8 & 23 & 6 & 5,662 & 19,583 & 5,526 & $17.79 \%$ & $59.04 \%$ & 16 \\
Not Return & 5 & 16 & 7 & 3,034 & 15,908 & 6,438 & $9 \%$ & $52 \%$ & 18 \\
\hline \hline
\end{tabular}

*Significance level at 0.05

Given $1=$ return intention and $0=$ not return intention

Stepwise Regression Analysis of Return, Income, Employment and Legal Satisfaction

In measurement of income, employment and legal satisfaction, there are more than one issue involved. Further to figure from each issue, the author also used a total of average outcomes of all issues in each satisfaction for calculation. 
TABLE 6. Pearson correlation analysis between intention to return and remitting behaviors, amount per year, proportion to income and remitting frequency

\begin{tabular}{llll}
\hline \hline Remitting Behaviors & Intention to return & & \\
\hline & $\mathrm{R}$ & Sig. & Order \\
\hline Amount per year & $.207^{*}$ & .039 & 2 \\
Proportion to income & $.219^{*}$ & .029 & 1 \\
Remitting frequency & .160 & .111 & - \\
* Significance level at 0.05 & \multicolumn{3}{l}{} \\
Given 1 = return intention and $0=$ not return intention &
\end{tabular}

TABLE 7. Stepwise regression analysis between intention to return and income satisfactions

\begin{tabular}{llc}
\hline \hline Income Satisfactions & \multicolumn{2}{l}{ Intention to Return } \\
\hline & $\mathrm{R}$ & Sig. \\
\hline - Is your income sufficient for living and meeting with living expenses? & .057 & .575 \\
- Does your current income meet your expectation that you set before & .012 & .910 \\
moving to Australia? & .101 & .317 \\
- Is your income consistent with your education and capacity? & .090 & .375 \\
- How is your opportunity to gain more income? & .078 & .440 \\
- Total income satisfactions & & \\
*Significance level at 0.05 & &
\end{tabular}

0.05

Given $1=$ return intention and $0=$ not return intention

First analysis is intention to return and income satisfaction. The outputs of this analysis are in the same direction that is intention to return does not have linear relationships with all issues of income satisfaction, sufficience for living, meeting expectation, consistent with workers' profiles and opportunity for a better income, with all significance levels larger than 0.05 .

Secondly, the analysis of intention to return and employment satisfaction is not far from the income satisfaction. The output marks significance of only one from four issues, "Comparing to Thailand, workers are treated better in Australia" with Stepwise Regression Coefficient (R) of -0.283 . The negative result implies that respondents who are satisfied in this issue prefer remaining in Australia to returning to Thailand. The result can simply say that intention to return does not have linear relationships with a total employment satisfaction.

The last analysis is the relationship between intention to return and legal satisfaction. Since there are six questions applied for three legal issues, visa regulations, taxation and labor protection, the outcome of each issue is going to be explained separately. Beginning with visa regulations, Stepwise Regression Coefficient indicates an overall relationship at the coefficient of -0.320 , while there is no linear relationship with the specific issue of visa regulations for family members where significance level is larger than 0.05 . The strongest significant relationship between intention to return and supportive visa regulations for their Australian Citizenship and Permanent Residency can be identified at a coefficient of -0.401 . The negative figure means the more they are satisfied in this issue, the more they prefer not to return to Thailand.

Despite without sign of linear relationship between intention to return and the overall taxation, Stepwise Regression analysis still gives weak significance to a relationship to the question that "Does paying taxes in Australia benefit you more than paying in Thailand?" with a coefficient of -0.254 . Like income satisfaction, we can imply from the negative figure that the satisfaction on this issue will give negative intention to return to Thailand. 
TABLE 8. Stepwise regression analysis between intention to return and employment satisfactions

\begin{tabular}{lll}
\hline \hline Employment Satisfactions & Intention to Return \\
\hline & $\mathrm{R}$ & Sig. \\
\hline - Is your current employment secured? & .019 & .850 \\
- Does your employment offer you promotion or progress opportunity? & .116 & .250 \\
- How is your opportunity to gain more income? & $-.283^{* *}$ & .004 \\
- Comparing to Thailand, you as a worker are treated better than in Australia. & .186 & .064 \\
Total employment satisfactions & .188 & .061 \\
\hline \hline
\end{tabular}

*Significance level at 0.05

Given $1=$ return intention and $0=$ not return intention

TABLE 9. Stepwise regression analysis between intention to return and visa regulations

\begin{tabular}{lll}
\hline \hline Visa Regulations & Intention to Return \\
\hline & $\mathrm{R}$ & Sig. \\
\hline - Do regulations support you to become an Australian permanent resident and citizen? & $-.401^{* *}$ & .000 \\
- Do visa regulations obstruct you to bring your family to live in Australia with you? & .159 & .114 \\
Total visa regulations satisfactions & $-.320^{* *}$ & .001 \\
\hline *Significance level at 0.05
\end{tabular}

*Significance level at 0.05

Given $1=$ return intention and $0=$ not return intentionn

TABLE 10. Stepwise Regression Analysis between intention to return and taxation

\begin{tabular}{lll}
\hline \hline Taxation Satisfaction & \multicolumn{2}{c}{ Intention to Return } \\
\hline - Are taxes you have paid worth what you have received? & .052 & .606 \\
- Does paying taxes in Australia benefit you more than paying in Thailand? & $-.254^{\prime}$ & .011 \\
Total taxation satisfaction. & .179 & .075 \\
\hline *Significance level at 0.05 & & \\
Given 1 = return intention and $0=$ not return intention &
\end{tabular}

TABLE 11. Labor protection

\begin{tabular}{|c|c|c|}
\hline Labor Protection & \multicolumn{2}{|c|}{ Intention to Return } \\
\hline - Are you better protected by labor law in Australia than in Thailand? & .192 & .052 \\
\hline - If you have any argument relating to work, you are confident that you will be fairly treated by labor law? & $-.207^{*}$ & .038 \\
\hline Are you being treated as equally as Australians? & $-.270 * *$ & .007 \\
\hline Total labor protection satisfaction & $-.267 * *$ & .007 \\
\hline
\end{tabular}

*Significance level at 0.05

Given 1 = return intention and $0=$ not return intention

The most outstanding result among other legal issues is labor protection. The analysis shows two significances from three questions, namely "If you have any argument relating to work, you are confident that you will be fairy treated by labor law?" and "Are you being treated as equally as Australians?" with the significance of -0.207 and -0.270 respectively. The overall labor protection satisfaction is also related to intention to return at the significance of -0.267 . From the figures, it can be said that the satisfaction in labor protection encourages respondents to remain working in Australia.

\section{DISCUSSIONS}

One of the two purposes of this study is to test the applicability of the existing theories, New Economics of Labor Migration (NELM) and Three Waves Theory by Poirine, for Thai migrant workers in Australia case. The survey was conducted with a hundred of Thai workers who are currently legally employed in five service industries on ANZSIC catego- 
rization. Using Pearson Correlation analysis, the results show some agreement between Thai case and both theories. That is to say intention to return to home country of Thai workers in Australia is related to their remitting behaviors in terms of the amount per year and proportion to their incomes. On the contrary, it does not indicate a significant relation with remitting frequency. According to the descriptive analysis, respondents who have intention to return send their income back home average 5,662 AUD a year or $17.79 \%$ of their annual income while ones who have intention not to return send only 3,034 AUD a year or $9 \%$ of annual income. This implies that Thai migrant workers who have intention to return home remit more money back home than those who have intention not to return.

Associated with knowing how intention to return affects remitting behaviors, this study also identifies factors that influence the intention. The author brought the factors which were discussed in the two conflicting approaches, NELM and Neoclassical Economic Theory, to be variable factors. In addition, legal aspect which is rarely found as a return determinant in previous studies is also raised to be one of the factors. The author first hypothesized that a relation between income and employment satisfaction and intention to return would be in line with NELM that is returnees are those who have achieved their economic goals: higher incomes, accumulation of savings and better jobs.

Surprisingly, the result of analysis which was run by Stepwise regression process does not agree neither with NELM nor Neoclassical Economic Theory. It does not demonstrate significant effect of income satisfaction on return intention like what was previously discussed in these two approaches. This contradiction can be explained from the descriptive analysis of surveyed population which presents average incomes of return and not-return group and it shows that the average incomes of these two groups are only slightly different, 2,618 AUD per month for return group and 2,484 AUD per month for not-return group. As a result, income satisfaction is not primary factor of intention to return to home country.

Speaking of employment satisfaction, although, the result does not show significant relation between intention to return and overall employment satisfaction, it reveals that intention to return can still be influenced by the satisfaction of labor treatment in Australia comparing to the treatment they receive in Thailand. This result rejects the hypothesis since ones who are more satisfied in this employment issue have intention to remain in Australia instead of intending to return to Thailand as first hypothesized. It means returnees are likely to be those who have not achieved their employment goals.

More interestingly, legal satisfaction becomes an important factor that determines return intention with significant result. Legal satisfaction is separated into three issues, visa regulations, taxation and labor protection. Stepwise regression coefficients show significance on two of these three issues, visa regulations and labor protection. It is discovered that respondents who are satisfied with visa regulations are likely to remain in Australia permanently. The strongest result is on labor protection of Australia which appears to be one of the not-return determinants. Respondents, who do not wish to return, have confidence that in any case of labor arguments, they will be protected by Australian labor law and there is no feeling of being discriminated.

Even though, overall taxation satisfactions cannot convince return intention, one issue of them does. Regression coefficient significantly indicates that those who are more satisfied in benefits returned from taxes they pay in Australia than that they pay in Thailand do not wish to return to Thailand permanently. As this study is the economic law integration, some legal instruments are used to describe the above economic outcomes. Comparative analysis between Fair Work Act 2009 of Australia and Labor Protection Act B.E.2541 of Thailand can partly explain the difference of labor standards of the two countries. Fair 
Work Act 2009 apparently gives more flexibility to work conditions than Thai Labor Protection Act does. Furthermore, this act also covers the discrimination and unfair treatment so that migrant workers can be confident in Australian labor protection system. With better working conditions and labor standards, it is not surprising that why Thai workers wish to remain and work in Australia permanently.

\section{CONCLUSION AND RECOMMENDATIONS}

The analysis shows that workers who experienced supportive visa regulations for their residential status are likely to remain in Australia. Benefits from paid taxes are also counted as one of the not-return determinants despite Thai workers, as foreigners, are being charged more than Australians are. It could be resulted by the low rate category of taxation, $5 \%$ or the next rate from the exemption, where majority of Thai workers fall into. Consequently, workers may not be aware of tax burden and would more enjoy working and receiving benefits.

Migration program under Migration Act 1958 also offers different migration pathways to foreigners to enter the country, namely Family Stream and Skill Stream. Under the Skill Stream, it also offers varied options of visas so that foreigners can choose the most appropriate pathway for themselves. This supportive immigration system is also one of the factors that encourage Thai workers to seek a way to live in Australia permanently.

\section{REFERENCES}

Ahlburg, Dennis A., and Richard PC Brown. 1998. Migrants' intentions to return home and capital transfers: A study of Tongans and Samoans in Australia. The Journal of Development Studies 35, no. 2: 125-151, 1998.

DOI: $10.1080 / 00220389808422567$

Atienza, Aldrin P., and Alan John W. 2013. Remittance for investment decisions: A case of overseas Filipino workers in

Ta iwan. Paper presented at the Proceedings of 19th International Business Research Conference, Monash University,

Caulfield, Melbourne, AU. DOI: 10.2139/ssrn.2174773

Australian Bureau of Statistics. 2006. Labour market outcomes of migrants. Australian Labour Market Statistics. Can- berra. URL: goo.gl/48xLrZ (accessed November 14, 2016).

Beasley, Tamerlaine, Philip Hirsch, and Sọimāt Rungmanī. 2014. Thailand in Australia. Sydney Southeast Asia Centre, Uni- $\quad$ versity of Sydney, Sydney, AU.

Bouoiyour, Jamal, and Amal Miftah. 2014. Socio-economic profile of return migrants: Case of Moroccan migrants resident in France. European Economic Letters 3, no. 1: 26-31.

Brown, Richard PC, Gareth D. Leeves., and Prabha Prayaga. 2012. An analysis of recent survey data on the remittances of Pacific island migrants in Australia. School of Economics, University of Queensland, Queensland, AU.

Davis, Kevin, and Martin Jenkinson. 2012. Remittances: Their role, trends and Australian opportunities. URL: goo.gl/IGVPBa

(accessed November 14, 2016).

Constant, Amelie, and Douglas S. Massey. 2002. Return migration by German guestworkers: Neoclassical versus new eco- $\quad$ nomic theories. International Migration 40, no. 4: 5-38. DOI: 10.1111/1468-2435.00204

Frantz, Anita, and Ashutosh Misal. 2016. Essential generic skills for human resources in hospitality: A literature review.

International Journal of Business and Administrative Studies 2, no. 5: 124-128. D0I: 10.20469/ijbas.2.10002-5

Glytsos, Nicholas P. 1997. Remitting behaviour of "temporary" and "permanent" migrants: The case of Greeks in Germany and Australia. Labour 11, no. 3: 409-435. DOI: 10.1111/1467-9914.00043

Goschin, Zizi, Monica Roman, and Aura Popa. 2010. Determinants of Romanian international migrants' remittances. Pa- per presented at the: 51st Congress of the European Regional Science Association: New Challenges for European Regions and Urban Areas in a Globalised World, Barcelona, ES.

Makina, Daniel. 2012. Determinants of return migration intentions: Evidence from Zimbabwean migrants living in South

Africa. Development Southern Africa 29, no. 3: 365-378. D0I: 10.1080/0376835X.2012.706034 
Poirine, Bernard. 1997. A theory of remittances as an implicit family loan arrangement. World Development 25, no. 4: 589-611. DOI: 10.1016/S0305-750X(97)00121-6

Stark, Oded. 1991. The migration labor. Cambridge, MA: Basil Blackwell.

Stark, Oded, and David E. Bloom. 1985. The new economics of labor migration. The American Economic Review 75, no. 2: 173-178.

Webb, Sue. 2015. The feminisation of migration and the migrants VET policy neglects: the case of skilled women secondary migrants in Australia. Journal of Vocational Education \& Training 67, no. 1 (2015): 26-46.

Withers, Glenn. 1986. Migration and the labour market; Australian analysis. Discussion Paper no. 144, The Australian National Centre for Economic Policy Research, Australian National University, Canberra, AU.

Suhaili, Padil, Esa Ahmad, and Mohamed Jamal AAS. 2015. Soft skills construct for architecture graduate in accordance with industry requirements. International Journal of Humanities, Arts and Social Sciences 1, no. 3: 119-123.

DOI: $10.20469 /$ ijhss.20002-3

The World Bank. 2014. Migration and remittances: Recent developments and outlook* special topic: Forced migration. URL: goo.gl/SNbliy (accessed November 14, 2016).

Thailand Overseas Employment Administration. 2015. Statistics reports that job seekers request to travel abroad. URL: goo.gl/EKMnrR (accessed November 14, 2016).

— This article does not have any appendix. - 